\title{
Strain-induced phase changes within cold basal ice from Taylor Glacier, Antarctica, indicated by textural and gas analyses
}

\author{
Denis SAMYN, ${ }^{1}$ Sean J. FITZSIMONS, ${ }^{2}$ Reginald D. LORRAIN ${ }^{1}$ \\ ${ }^{1}$ Laboratoire de Glaciologie, Département des Sciences de la Terre et de l'Environnement, Université Libre de Bruxelles, \\ CP 160/03, Avenue F.D. Roosevelt 50, B-1050 Brussels, Belgium \\ E-mail: desamyn@ulb.ac.be \\ ${ }^{2}$ Department of Geography, University of Otago, PO Box 56, Dunedin, New Zealand
}

\begin{abstract}
This paper reports detailed textural and gas measurements conducted in cold basal ice $\left(-17^{\circ} \mathrm{C}\right)$ from the margin of Taylor Glacier, an outlet glacier of the East Antarctic ice sheet. The analyzed samples were retrieved from a basal ice sequence excavated at the end of a subglacial tunnel dug near the glacier snout. The basal sequence exhibits two contrasting ice facies, defined as the englacial and stratified facies. On the one hand, analysis of ice crystal textures from the basal ice sequence provides evidence for localized ductile deformation, especially within the stratified facies where significant dynamic recrystallization was detected. On the other hand, high-resolution gas analyses reveal that strong changes in gas composition occurred at the structural interfaces of the stratified facies. These gas composition changes are typical of melting-refreezing processes but are not associated with any significant loss of gas volume. Given the specific subglacial thermal conditions at the margin of Taylor Glacier, we interpret this phenomenon as resulting from microscopic phase changes involving selective gas redistribution through the pre-melt phase. It is argued that such processes may play an important role in the post-genetic geochemical evolution of cold debris-laden ice and may be enhanced through intense strain conditions.
\end{abstract}

\section{INTRODUCTION}

Over recent decades, research related to the deformation of debris-rich ice has mainly focused on the behaviour of glaciers with unconsolidated beds and on the influence of subglacial sediment deformation on glacier motion (e.g. Boulton, 1970, 1996; Clark, 1993, 1995). Until recently, it was generally assumed that basal sliding and bed deformation do not operate beneath cold-based glaciers and ice sheets (e.g. Sugden and John, 1976; Paterson, 1994). Such ice bodies would consequently be unable to erode their bed or to entrain sediments (e.g. Kleman, 1994). There is, however, now a growing body of evidence suggesting that basal deformation may be strongly active beneath coldbased glaciers, mostly because of the increased occurrence of liquid water veins within basal ice as well as at the ice/ bedrock interface (e.g. Echelmeyer and Wang, 1987; Cuffey and others, 1999; Souchez and others, 2004). This leads to the assertion that liquid water can play an important role in the dynamics of cold ice masses. In other respects, the influence of liquid veins on the geochemical composition of natural ice has not attracted much attention, despite the recent publication of convincing models (e.g. Rempel and others, 2001). Nevertheless, liquid-like veins present at the triple junctions and nodes of polycrystalline ice constitute an interconnected network (Nye, 1989) that can facilitate the transport of soluble impurities and therefore potentially influence the geochemical signals recovered from ice cores, even at temperatures well below the freezing point $\left(\leq-10^{\circ} \mathrm{C}\right.$; e.g. Dash and others, 1995). In this context, the aim of this paper is to contribute to the understanding of the potential influence of thin liquid films on the geochemical composition of cold basal ice from glaciers and ice sheets. Through detailed study of ice crystal textures and gas content, i.e. gas composition and total gas volume, we investigate the factors that led to gas segregation within cold basal debris-rich ice from the margin of Taylor Glacier, Antarctica.

\section{FIELD SITE}

Taylor Glacier is an outlet glacier draining part of the East Antarctic ice sheet through Taylor Valley (Dry Valleys, Victoria Land) and toward McMurdo Sound (Fig. 1). Almost $100 \mathrm{~km}$ long, this glacier runs from Taylor Dome to the perennially ice-covered Lake Bonney, and forms at its terminus a $20 \mathrm{~m}$ high cliff overlooking an ice-and-debris apron. The ice thickness of Taylor Glacier is about $450 \mathrm{~m}$ on average (Calkin, 1974), but can exceed $1000 \mathrm{~m}$ in restricted subglacial depressions of the bedrock. At the glacier snout, Robinson (1984) measured a mean ice surface temperature of $-17^{\circ} \mathrm{C}$. Whilst the central area of lower Taylor Glacier might be at or close to the pressure-melting point (Robinson,

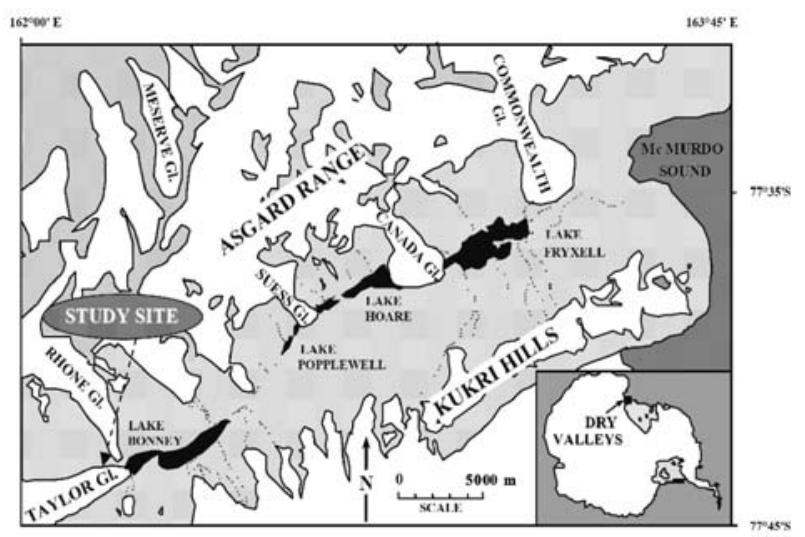

Fig. 1. Map of Taylor Valley, Antarctica, showing location of the marginal zone of Taylor Glacier. 


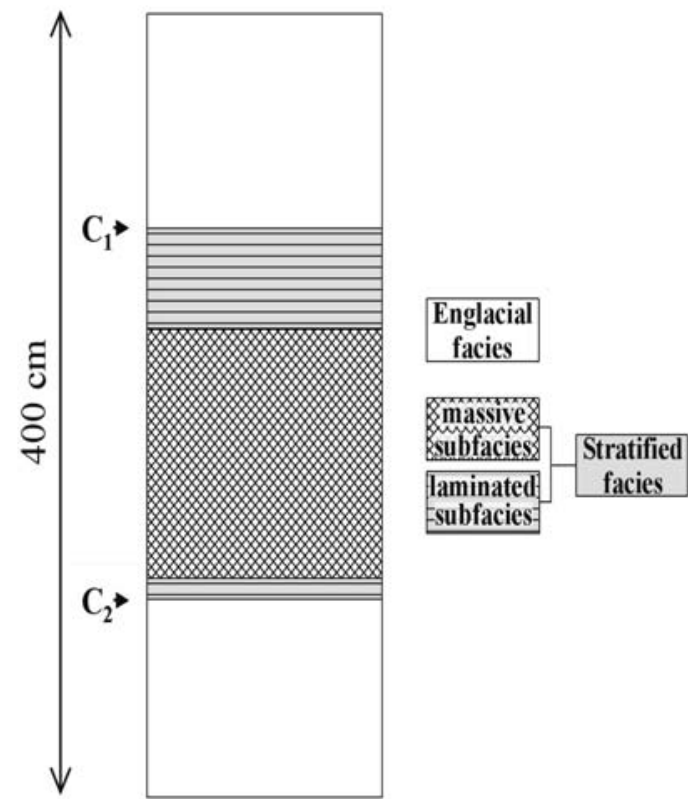

Fig. 2. The debris-laden ice sequence excavated from a shaft dug at the end of a $25 \mathrm{~m}$ long tunnel. This tunnel is situated $1.4 \mathrm{~km}$ from the glacier snout. Ice exposure shows two main stratigraphical units corresponding to clean bubbly ice (englacial facies) and debris-rich ice (stratified facies). The relative thickness of these units is shown to scale. $\mathrm{C}_{1}$ and $\mathrm{C}_{2}$ mark respectively the upper and lower contacts between the englacial and the stratified facies.

1984), at least the marginal zone of the glacier is generally considered to be cold-based (e.g. Calkin, 1974; Robinson, 1984; Denton and others, 1993).

\section{SAMPLING AND ANALYTICAL PROCEDURES}

Two subglacial tunnels have been dug from the left margin of the glacier, parallel to the local flowlines. In this paper, we report the results of investigations conducted in one of these, a $25 \mathrm{~m}$ long tunnel dug $1.4 \mathrm{~km}$ upstream from the snout during the 1999/2000 austral summer. A vertical shaft (about $4 \mathrm{~m}$ high and $1.5 \mathrm{~m}$ wide) was excavated at the end of this tunnel, revealing a debris-laden ice sequence at the homogeneous temperature from $-17^{\circ} \mathrm{C}$. The bottom of the shaft did not reach the bedrock, although investigations conducted in the other tunnel close to the one discussed here suggest that the bedrock should be within a few metres of the bottom of the shaft. In the shaft, ice blocks (about $10 \mathrm{~cm}$ wide and $30 \mathrm{~cm}$ high) were sampled along a single vertical profile with the aid of electrical chain-saws equipped with tungsten carbide cutters. The blocks were then wrapped into polyethylene bags, stored at about $-18^{\circ} \mathrm{C}$, and transferred to the cold laboratory in Brussels.

As a first step in the analytical procedure, vertical thin sections were cut all along the sampled profile. Clean ice was thin-sectioned with the aid of a traditional biological microtome (Leitz 1400), whereas debris-laden ice was sectioned using a diamond-wire saw (Well 6234). The cutting techniques have been described by Langway (1958) and Tison (1994) respectively.

Gases entrapped in the ice were analyzed for their total volume and composition $\left(\mathrm{CO}_{2}, \mathrm{O}_{2}\right.$ and $\left.\mathrm{N}_{2}\right)$. Gas composition was measured by gas chromatography (Varian 3300) following the dry-extraction technique described by

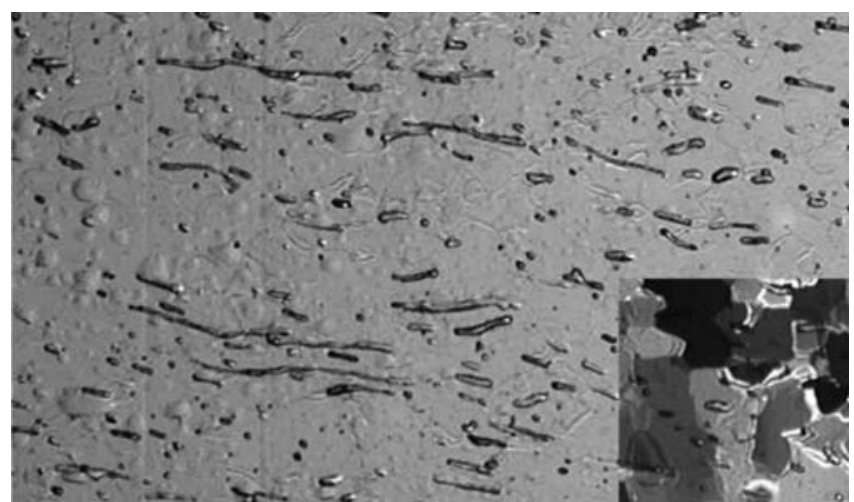

Fig. 3. Micrograph of elongated gas bubbles from a clean bubbly ice layer (height of view: $2 \mathrm{~cm}$ ). The crystal texture is observable at the bottom right corner of the picture (polarized light).

Raynaud and others (1982) and Barnola and others (1983). Total gas volume was determined using a Toepler pump following the melting-refreezing method described by Raynaud and others (1988) and Blunier and others (1993). Both gas composition and total gas volume analyses were performed on samples with a vertical resolution of $1 \mathrm{~cm}$. Residual standard deviation was about $3 \%$ for $\mathrm{CO}_{2}$ and $0.5 \%$ for $\mathrm{O}_{2}$ and $\mathrm{N}_{2}$ measurements. Because of the low quantity of ice available in the laminated subfacies (see below), total gas volume analyses were performed on smaller samples ( 10 g) than required $(20-30 \mathrm{~g})$ in that part of the sequence. The corresponding analytical accuracy was consequently decreased. Experiments in the laboratory showed that, for ice samples smaller than about $20 \mathrm{~g}$, the lower the volume/ surface sample ratio the larger the loss of gas volume due to increased relative air-bubble sectioning. The results provided in this study for the laminated subfacies thus correspond to minima. The maximum analytical imprecision of the total gas content measurements in the laminated subfacies was close to $10 \%$. No gas analyses were conducted within the central part of the sequence (where the debris concentration is close to saturation) as no reliable gas extraction technique is yet available for ice containing such a debris content.

\section{STRUCTURE OF THE BASAL ZONE}

A distinctive sequence of debris-laden ice is exposed at the margin of Taylor Glacier. This sequence strongly contrasts with the overlying bulk clean ice. This can also be observed in the shaft excavated at the end of the studied subglacial tunnel. Two main facies were identified following common basal ice nomenclatures provided by, for example, Lawson (1979), Hubbard and Sharp (1989) and Knight (1994): the stratified facies (mostly composed of debris-rich ice layers interspersed with layers of clean bubbly ice) and the englacial facies (consisting of clean bubbly ice, which stratigraphically overlies and underlies the former facies). Due to its variability in debris content, the stratified facies was divided into two subfacies: the massive subfacies and the laminated subfacies. The vertical arrangement of all these stratigraphical units is sketched in Figure 2.

\section{Englacial facies}

Extending for about $1 \mathrm{~m}$ at both the top and bottom of the shaft, the englacial facies denotes highly uniform 


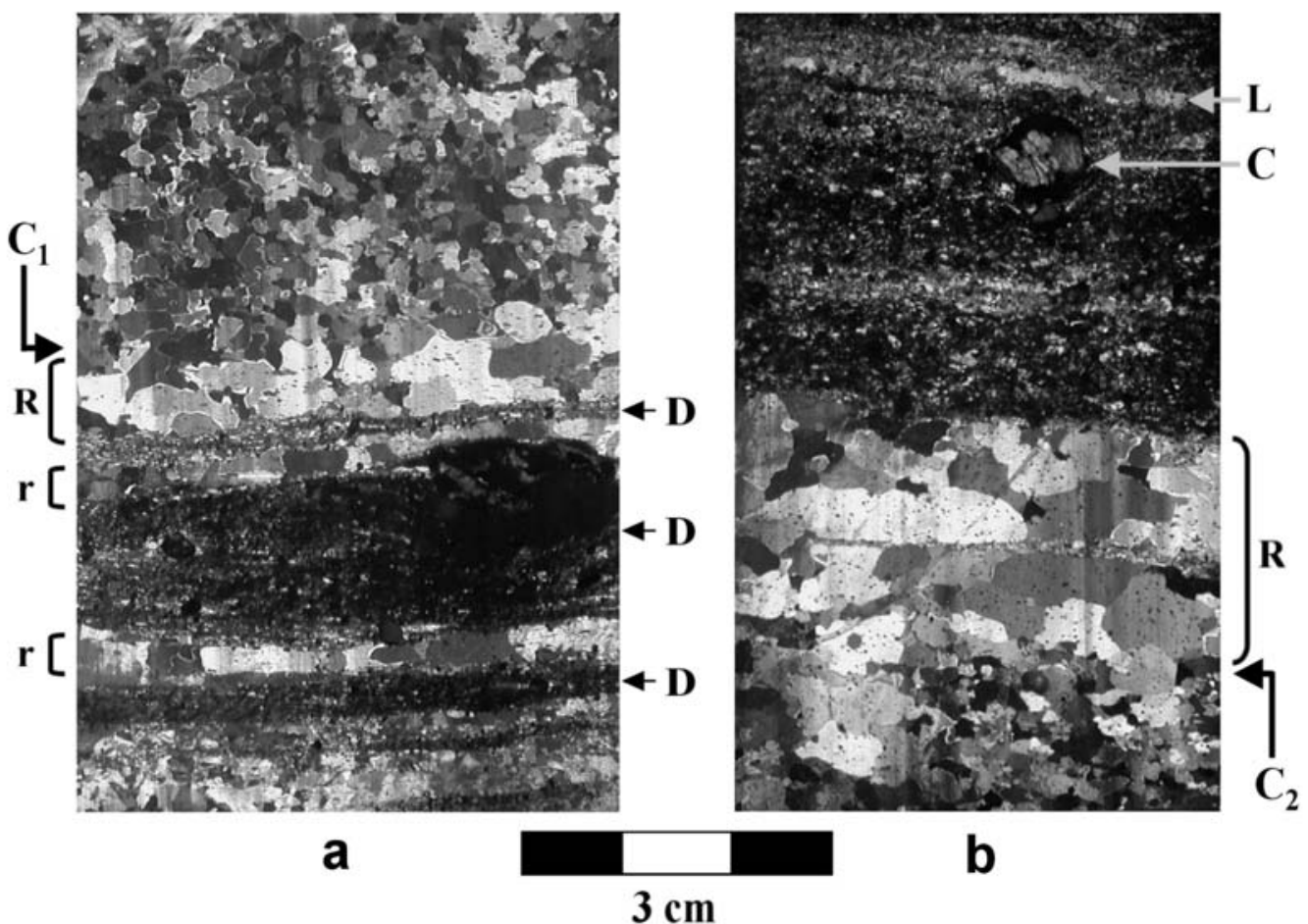

Fig. 4. Micrographs of thin sections between crossed polarizers, illustrating ice crystal textures from the stratified facies. (a) Example of localized recrystallization $(R)$ at the boundaries between clean ice layers and debris-rich ice layers (D) from the laminated subfacies. Migration recrystallization is strongly localized within $1 \mathrm{~cm}$ thick zones in the clean bubbly ice layers. Some of the clean ice layers are characterized by a one-crystal thickness $(r)$. $C_{1}$ marks the upper contact between the englacial and the stratified facies. (b) Example of localized recrystallization $(R)$ at the boundaries between the lower limit of the massive subfacies and a clean bubbly ice layer from the laminated subfacies. Migration recrystallization is strongly localized within two $1 \mathrm{~cm}$ thick zones of clean ice separated by a millimetric sediment layer. $\mathrm{L}$ denotes an example of flow-conformable ice crystal ribbons in the debris-rich ice matrix, and $\mathrm{C}$ stands for a coated clast. $\mathrm{C}_{2}$ marks the lower contact between the stratified and the englacial facies.

characteristics (Fig. 3). It is made up of white and bubbly ice containing $<0.05 \%$ of debris by volume. The ice crystals are polygonal, with a mean crystal size of $2.2 \mathrm{~mm}$ in diameter, giving the ice a granular texture. The gas bubbles are mostly tubular and define a clear lineation within the facies. Their longest axis is parallel to the general ice and debris stratifications, and their length ranges from $<0.5$ to $6 \mathrm{~mm}$. Their diameter shows a maximum of $0.5 \mathrm{~mm}$. When present, debris appears in the form of dispersed silt particles that concentrate in plurimillimetric ice layers. Debris content in these layers may then reach a few per cent by volume.

\section{Stratified facies}

The stratified facies contrasts with the englacial facies in that its debris content is generally higher and its structure more variable. Figure 4 shows that a well-defined planar contact resulting from a sharp change in debris concentration separates the two ice facies. The stratified facies lies in the middle part of the sampled ice sequence (in between the two zones of englacial ice) and extends vertically for about $2 \mathrm{~m}$ (Fig. 2). It is made up of extensive layers of debris-rich ice alternating with layers of clean bubbly ice. The facies as a whole is an assemblage of the two following subfacies.

\section{Laminated subfacies}

The laminated subfacies marks the contact zone between the englacial facies and the stratified facies (Fig. 2). It consists of a succession of debris-rich strata alternating with clean bubbly ice layers. Individual debris-rich strata are a few $\mathrm{mm}$ to a few $\mathrm{cm}$ thick, and are mostly composed of a silt-to-sand matrix (debris content is $30-50 \%$ by volume). The pore ice cementing debris particles shows ice crystals ranging from $<0.2$ to about $1.5 \mathrm{~mm}$ in diameter. The debris-rich strata present a discrete foliated aspect due to closely spaced debris laminations that are sometimes separated by flow-conformable lenses of clean ice. These lenses, some of which are pinching out, with others merging laterally, have dimensions ranging from $<1 \mathrm{~mm}$ to a few $\mathrm{cm}$. Small-scale strain figures such as pressure shadows and winged patterns (after, e.g., Passchier and Simpson, 1986) were found throughout the debris-rich ice bands and occasionally within clean bubbly ice layers. These structures developed around millimetric to centimetric embedded rock clasts and have dimensions up to several $\mathrm{cm}$ (an example of $\delta$-pattern, marked as $\delta$, is given in Figure 7). Debris coatings around rock clasts were also observed (see C in Fig. 4).

The clean bubbly ice layers alternating with the debrisrich strata are a few $\mathrm{mm}$ to a few $\mathrm{cm}$ thick, and extend parallel to the local general stratification. They show a very low debris content $(<0.05 \%$ by volume). The bubbles within the clean bubbly ice layers appear in the same way as in the englacial facies. The ice crystal texture from the clean bubbly ice layers is generally also similar to that from the englacial facies. However, in the contact zone with debrisrich strata, ice crystals show a sharp increase in dimensions and aspect ratio (Fig. 4a and b). Crystals are then highly 

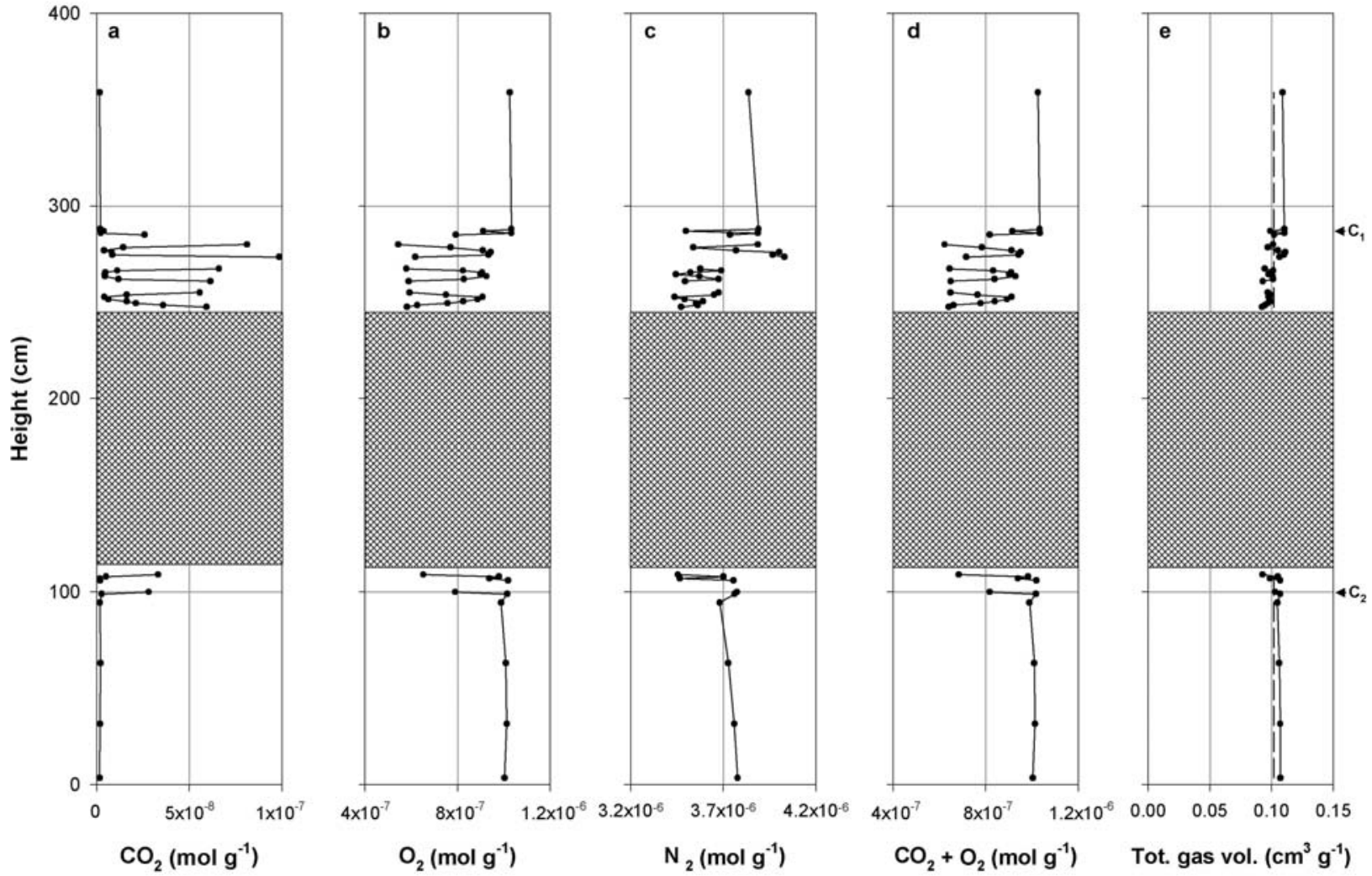

Fig. 5. Results of gas analyses in the basal ice sequence from Taylor Glacier. The shaded zone corresponds to the massive subfacies, where no gas extraction technique was available. $C_{1}$ and $C_{2}$ mark respectively the upper and lower contacts between the englacial and the stratified facies. (a-d) $\left[\mathrm{CO}_{2}\right](\mathrm{a}),\left[\mathrm{O}_{2}\right](\mathrm{b}),\left[\mathrm{N}_{2}\right](\mathrm{c})$ and $\left[\mathrm{CO}_{2}+\mathrm{O}_{2}\right]$ (d) profiles $\left(\mathrm{mol} \mathrm{g}^{-1}\right)$. (e) Total gas volume profile $\left(\mathrm{cm}^{3} \mathrm{~g}^{-1}\right)$. The dashed line stands for the mean total gas volume.

interlocked, eventually show undulous extinction and subgrain structure, and can be up to $28 \mathrm{~mm}$ long and $6 \mathrm{~mm}$ wide. These elongated crystals define distinctive linear features, which we refer to as ice crystal ribbons, in which the long axes of the crystals are similarly oriented. These conspicuous changes in crystal texture appear systematically and only in the first $\mathrm{cm}$ of clean bubbly ice directly in contact with sediment-rich strata. In addition, some clean ice layers characterized by a one-crystal thickness were observed in between or within debris-rich strata (Fig. 4a).

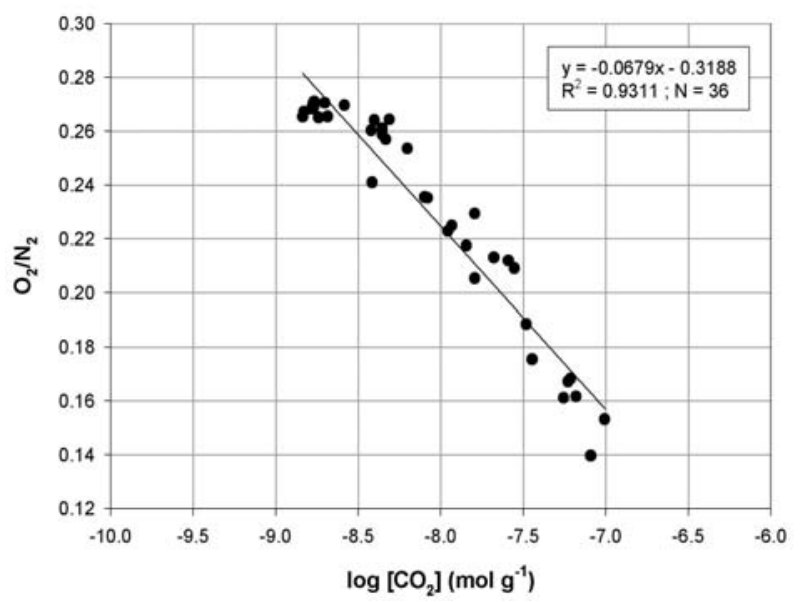

Fig. 6. $\mathrm{CO}_{2}$ vs $\mathrm{O}_{2} / \mathrm{N}_{2}$ profile from the basal ice sequence. Note the logarithmic scale of the $x$ axis.
The ribboning texture of these particular layers is even more defined than at the contact with debris-rich ice layers.

\section{Massive subfacies}

In between the two zones of laminated ice lies a massive and $>1 \mathrm{~m}$ thick layer of heavily debris-laden ice; this is the massive subfacies. Debris content is generally close to $50 \%$ by volume. Ice is close to pore saturation but can segregate into flow-conformable clean ice lenses (see L in Fig. 4b). These ice lenses are similar to those from the laminated subfacies but are somewhat smaller (max. 20-30 mm long and $0.5-1 \mathrm{~mm}$ thick). Some air-filled cavities were also detected on the stoss side of some of the largest debris particles (pebbles to boulders).

\section{ANALYTICAL RESULTS}

\section{Gas content in the basal ice}

Results of gas analyses from the various ice facies are presented in Figure 5. Gas concentrations are provided in absolute molarity $\left(\mathrm{mol} \mathrm{g}^{-1}\right)$ to account for potential differential loss of gas species. $\mathrm{CO}_{2}$ concentrations range from about $1.458 \times 10^{-9} \mathrm{~mol} \mathrm{~g}^{-1}$ (i.e. $305 \mathrm{ppmv}$ ) in the englacial facies to $>9.492 \times 10^{-8} \mathrm{~mol} \mathrm{~g}^{-1}$ (i.e. $>20000 \mathrm{ppmv}$ ) in the laminated subfacies (Fig. 5a). $\mathrm{CO}_{2}$ varies within an extremely narrow range in the englacial facies, whereas it shows a large variability within the laminated subfacies. The same is true for $\mathrm{O}_{2} / \mathrm{N}_{2}$, which has a mean value of 0.268 in the englacial facies and ranges between 0.140 and 0.272 in the laminated subfacies (Fig. 6). All along the sequence, the 

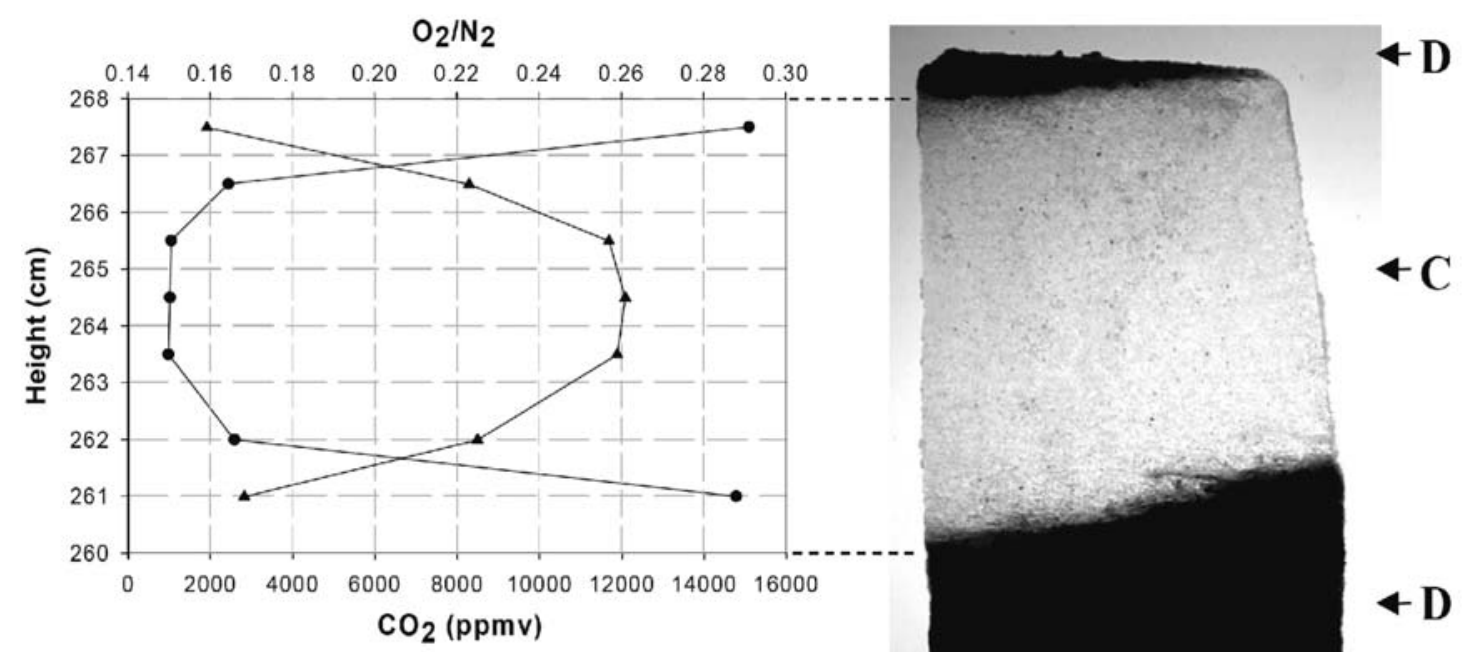

C
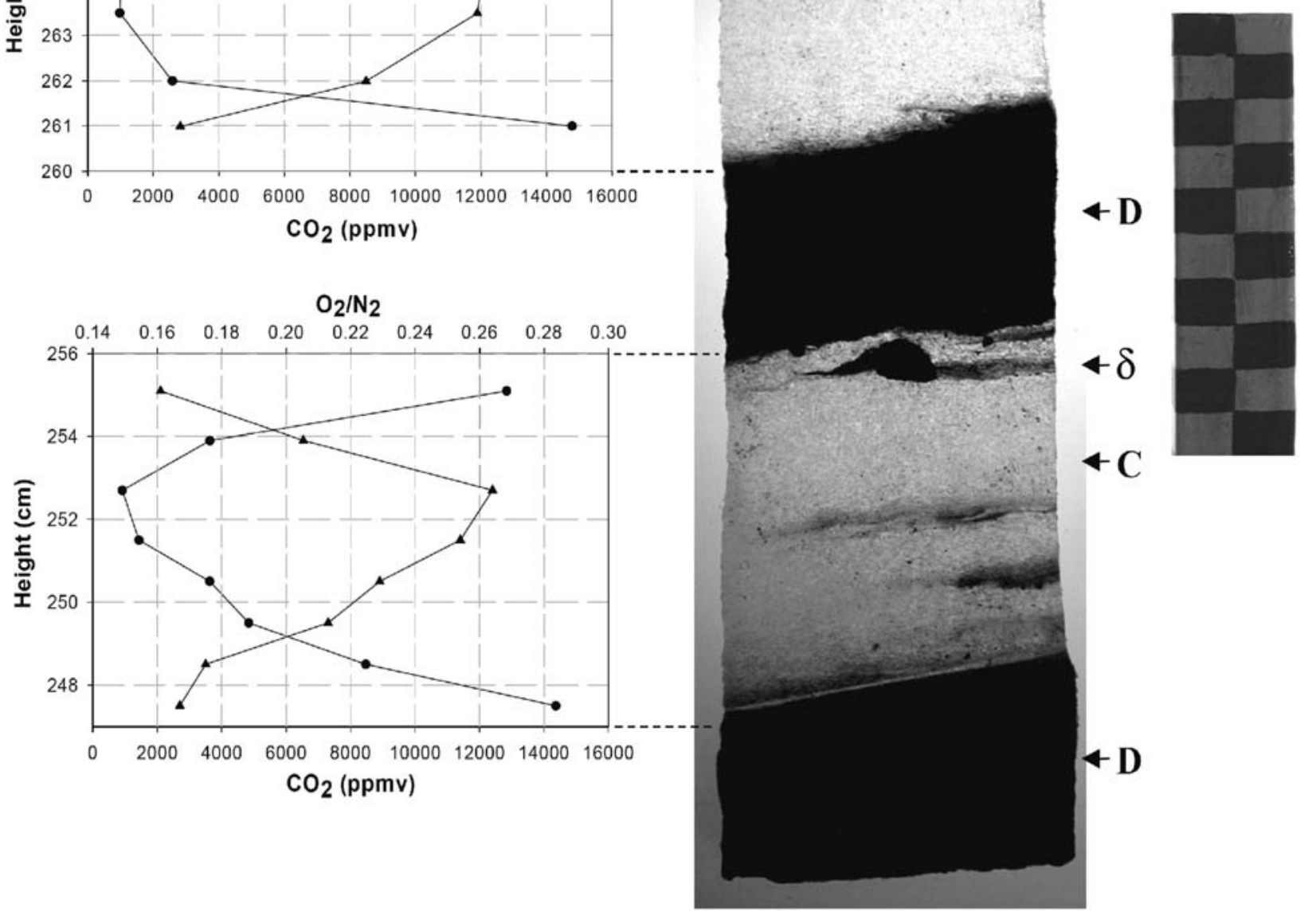

Fig. 7. Examples of gas composition variability within clean bubbly ice layers (C) from the laminated subfacies. The $\mathrm{CO}_{2}$ concentration reaches several thousands of ppmv at the interface with the debris-rich ice bands (D). The $\mathrm{O}_{2} / \mathrm{N}_{2}$ ratio ranges from about 0.16 to about 0.26 in between the debris-rich ice layers (D). $\delta$ points towards a $\delta$-shaped strain figure observed in a clean bubbly ice layer. The scale bar is $10 \mathrm{~cm}$ long.

$\mathrm{O}_{2}$ profile appears as a mirror image of the $\mathrm{CO}_{2}$ profile (Fig. 5b). Figure 6 brings out the remarkable negative correlation between these two sets of values. Figure 7, which is a blow-up of the $247-268 \mathrm{~cm}$ depth interval of Figure 5, highlights another striking feature of the gas composition profile: C-shaped $\mathrm{CO}_{2}$ concentration curves are systematically present within the clean bubbly ice layers of the laminated subfacies. These C-shaped curves denote a sharp $\mathrm{CO}_{2}$ increase from the central part of the clean ice layers toward their boundaries with the adjoining debris-rich strata.

Total gas volume is high all over the profile (Fig. 5e), with values ranging from 0.098 to $0.110 \mathrm{~cm}^{3} \mathrm{~g}^{-1}$ in the englacial facies (mean value on 7 samples $=0.106 \mathrm{~cm}^{3} \mathrm{~g}^{-1}$ ), and from 0.092 to $0.111 \mathrm{~cm}^{3} \mathrm{~g}^{-1}$ in the clean bubbly ice layers of the laminated subfacies (mean value on 29 samples = $0.101 \mathrm{~cm}^{3} \mathrm{~g}^{-1}$ ). Despite the lower precision of total gas volume analyses close to the interface between the englacial facies and the laminated subfacies, a slightly decreasing trend of total gas volume is observable closer to this interface.
This apparent decrease is, however, not significant, being in the range of analytical uncertainty (max. 10\%).

\section{DISCUSSION}

\section{Evidence for ductile deformation in the stratified facies}

Ductile shear zones are known to accommodate significant amounts of deformation at the base of cold-based glaciers (e.g. Holdsworth, 1974; Echelmeyer and Wang, 1987; Fitzsimons and others, 1999, 2001; Cuffey and others, 2000). In the sampled ice sequence from Taylor Glacier, the geometry of the elongated bubbles and strain figures, as well as their consistency with the local general foliation, shows that large shear motion has taken place, or is taking place. The fact that the bubble alignment is strictly parallel to the main stratification indicates that simple shear caused the bubbles to stretch and rotate until they approached 
parallelism with the local flowlines (Hooke and Hudleston, 1978). Furthermore, the small-scale strain figures found in debris-rich ice are similar to those commonly observed in sheared rocks (e.g. Passchier and Simpson, 1986) and reveal that significant stress and strain variations may appear within a few $\mathrm{mm}$ in the laminated subfacies. Shearing processes have thus played a major role in the microscopic reorganization of the whole basal sequence.

\section{Localized recrystallization at structural interfaces}

Figure 4 shows that recrystallization has taken place at the boundaries between the clean bubbly ice layers and the debris-rich strata of the laminated subfacies. The coarse crystal size observed there, together with the development of a relatively high interlocking texture, clearly points to the predominance of grain boundary migration during recrystallization (e.g. Kamb, 1959, 1972; Anderton, 1974). This increase in grain-size appears to deviate from the generally accepted inverse correlation between grain-size and stress intensity (e.g. Jacka and Li, 1994), but can be explained by the concomitance of relatively high stress and temperature conditions. Indeed, deformation experiments in polycrystalline rocks revealed that high-stress conditions associated with temperatures above a critical level can lead to effective migration recrystallization (e.g. Guillope and Poirier, 1979). The latter phenomenon was also proposed as accounting for the production of ice crystals larger than $5 \mathrm{~cm}$ at the bottom of deep ice cores such as the Byrd and Greenland Icecore Project (GRIP) cores (e.g. Gow and Williamson, 1976; Thorsteinsson and others, 1995), where important temperature and strain-rate variations are known to occur. Such large rates of grain boundary migration were attributed to drastic changes in the grain boundary mobility at temperatures ranging between about $-13^{\circ} \mathrm{C}$ and the pressure-melting point (Gow and Williamson, 1976; Thorsteinsson and others, 1995; Castelnau and others, 1996). Migration recrystallization is less pronounced in our study than at the bottom of the deep ice sheets, but still suggests a transitory phase towards drastic textural changes.

In addition to variations in migration rates, preliminary crystallographic investigations have revealed clear changes in crystal lattice orientation at the boundaries between debris-free and debris-rich ice layers. The ice lattice orientations evolve from a tight single-pole fabric normal to the foliation in the clean ice, to a scattered, and eventually multiple-pole, fabric at the interface with debris-rich ice bands (Samyn and others, 2005). These changes also resemble those described at the bottom of the deep ice cores. Similar fabrics were also reported by Kamb (1959), Rigsby (1960) and Kizaki (1969) in experimental and natural bubbly ice subjected to deformation close to the pressuremelting point. Here we ascribe the observed recrystallization textures to localized shearing at the interface between the clean and debris-rich ice layers from the laminated subfacies. Indeed, given the sharp rheological contrast at these structural interfaces (as reported, e.g., by Lawson (1996) for Taylor Glacier and by Fitzsimons and others (1999) for Suess Glacier, Antarctica), stress heterogeneities are likely to arise, allowing differential strain at the interface and possibly variations in grain lattice rotation and grain boundary migration. Summing up, our crystallographic results point to the occurrence of localized dynamic recrystallization at the contact between rheologically contrasted types of ice.

\section{Gas composition variability in the laminated subfacies}

The $\mathrm{CO}_{2}$ concentration of meteoric ice is known to range between about 200 and 370 ppmv (i.e. between $\sim 9.00 \times$ $10^{-10}$ and $1.67 \times 10^{-9} \mathrm{molg}^{-1}$ ), and its total gas content between 0.075 and $0.140 \mathrm{~cm}^{3} \mathrm{~g}^{-1}$ (Martinerie and others, 1992; Etheridge and others, 1996). Ice from the englacial facies belongs to these ranges and thus results from firnification. The total gas volume of the stratified facies suggests the same genesis. Its gas composition, however, reveals the influence of another process that is leading to considerable $\mathrm{CO}_{2}$ enrichment together with $\mathrm{O}_{2}$ removal. The clear trend of the $\mathrm{CO}_{2}$ vs $\mathrm{O}_{2} / \mathrm{N}_{2}$ diagram in Figure 6 points to a single mode of formation but of variable intensity.

The clean bubbly ice layers from the laminated subfacies show very high $\mathrm{CO}_{2}$ concentrations (up to $>20000$ ppmv, i.e. $>9.492 \times 10^{-8} \mathrm{~mol} \mathrm{~g}^{-1}$ ), and their $\mathrm{O}_{2} / \mathrm{N}_{2}$ ratio is much lower than the atmospheric one (0.268). This composition cannot be explained by simple gas diffusion within the solid phase of the ice. Applying Fick's second law with diffusion constants for polycrystalline ice (e.g. Neftel and others, 1983), solid diffusion of $\mathrm{CO}_{2}$ would indeed take place over a distance of $<1 \mathrm{~cm}$ within $>10000$ years (Hemmingsen, 1959; Souchez, 1997). Knowing that a shorter time interval would reduce the distance over which solid diffusion may have been active, this process is clearly unable to explain the gas profile presented here, especially in view of the relatively rapid turnover of ice in the Dry Valley glaciers (inferred to be a few thousand years by Chinn, 1991). These compositional characteristics actually indicate the influence of meltingrefreezing processes in the course of basal ice evolution from meteoric ice (e.g. Weiss and others, 1972). However, whereas melting-refreezing processes are generally described as being accompanied by a significant loss of total gas volume (e.g. Berner and others, 1977; Souchez and others, 1993; Tison and others, 1993; Sleewaegen and others, 2003), the laminated subfacies shows a gas volume similar to that of meteoric ice. It is thus clear that small-scale melting-refreezing events involving minute loss of gas must be considered here.

\section{Effects of localized deformation on the liquid water content of basal ice}

From the gas characteristics described above arises the question of the origin of liquid water within the stratified ice. We already mentioned that Taylor Glacier can be considered as cold-based in its terminal zone, which implies strongly limited amounts of liquid water within bulk ice. In such conditions, the most likely source of liquid water is the somewhat connected liquid films persisting below the freezing point at intergranular and interfacial boundaries (e.g. Gilpin, 1979; Mader, 1992a, b; Dash and others, 1995). The thickness of these films is in the order of a few $\mu \mathrm{m}$ in cold glacier ice and increases exponentially with temperature, pressure and impurity content (Dash and others, 1995; Wettlaufer, 1999).

Wilson and others (1996) studied the behaviour of polycrystalline ice sheared at approximately $-1{ }^{\circ} \mathrm{C}$. They reported experiments during which deformation was localized along slip-lines corresponding to zones of high resolved shear stress. Melting was observed, initiating along the shear zones. The authors ascribed the melting phenomenon to localized strain incompatibility across crystal boundaries, 
particularly at triple-point junctions. From this was inferred the likelihood of higher-temperature spots being achieved at grain boundaries due to increased friction. Though these experiments were conducted at temperatures close to the melting point of bulk ice, the work of Wilson and others (1996) shows that localized deformation can effectively favour the development of interstitial liquid films.

We infer that the building of localized stress zones in polycrystalline ice can strongly influence the mobility of the liquid veins present at intercrystalline and interfacial boundaries. This is supported by theoretical and experimental research on frozen soils (e.g. Corte, 1962) and on fluid dynamics within polycrystalline ice (e.g. Nye, 1989; Mader, 1992a, b) and rocks (e.g. Hirth and Kohlstedt, 1995; Daines and Kohlstedt, 1997). These theories predict that variations in the temperature and stress fields can cause vein radius changes, inducing fluid flux gradients through the intercrystalline vein network. For a gas depletion to be observed within bulk ice, there is an obvious need of transfer of the involved gases, either by solid diffusion, by in situ chemical reactions or by migration in dissolved form through the meltwater. Regarding our study, it has already been argued that solid diffusion cannot be invoked to explain the observed alteration of gas composition. Furthermore, if gas consumption resulting from in situ reactions in the form of, for example, biologically mediated redox reactions had occurred within the ice, the sum $\left[\mathrm{O}_{2}\right]+\left[\mathrm{CO}_{2}\right]$ would have remained close to $21 \%$ by volume (i.e. about $1 \times 10^{-6} \mathrm{~mol} \mathrm{~g}^{-1}$ in glacier ice) (Souchez, 1997), which is obviously not the case here (Fig. 5c). These arguments strongly support our idea that the measured gas composition changes detected at the structural interfaces result from enhanced interactions between gas bubbles and minute liquid water volumes through localized melting-refreezing processes. An open system, however, must be considered to account for the selective loss or enrichment of gas observed.

\section{Gas segregation through the liquid vein system}

Models of gas segregation through melting-refreezing processes already exist in the literature (e.g. Weiss and others, 1972; Berner and others, 1977; Souchez and others, 1993), but these can only account for gas segregation leading to a substantial loss of total gas volume from bulk ice. In order to gain insight into the processes of gas composition alteration in cold debris-laden ice, we sketch below a conceptual model of gas segregation through freezing across the interstitial fluid phase.

There is empirical evidence to support the assumption that most soluble impurities are not located inside the ice crystal but are confined to the pre-melt phase (Mulvaney and others, 1988; Fukazawa and others, 1998). It has also been shown that the impurity content in veins and at grain boundaries is generally several orders of magnitude higher than that of bulk ice (Alley and others, 1986; Dash and others, 1995). This can be explained by the tendency of forming ice to reject solutes and particles from its lattice (Gross and others, 1975), which has the effect of concentrating impurities in the residual liquid phase (e.g. Glen and others, 1977; Dash and others, 1995). Building on the fact that gases entrapped in air bubbles can dissolve within liquid water (e.g. Weiss and others, 1972; Berner and others, 1977; Dash and others, 1995), it is reasonable to assume that, like other types of impurities, gases can segregate into the pre-melt phase.
Gas bubbles are located either within individual ice crystals or at the junction of neighbouring crystals within polycrystalline ice (e.g. Raymond and Harrison, 1975; Mader, 1992b). Besides, pre-melting is known to occur at ice/bubble interfaces (e.g. Lliboutry, 1971; Raymond and Harrison, 1975). Accordingly, if ice is subject to intense shearing, the probability that thin liquid films will meet entrapped air bubbles will increase as a result of liquid, grain-boundary and/or bubble migration. Considering the case where the ice/vein system is not at chemical equilibrium regarding its gas content, gas exchange is likely to occur at the interface between entrapped air bubbles and liquid veins. If so, since internal meltwater is initially almost free of any impurities (Berner and others, 1977), the relative concentration of highly soluble gas species will increase incrementally in the liquid phase, until a steady state is achieved. In this process, $\mathrm{CO}_{2}$, which is known to be highly soluble (e.g. Hemmingsen, 1959; Weiss and others, 1972), will segregate preferentially into the liquid phase. This will occur to a lesser extent for $\mathrm{O}_{2}$ and $\mathrm{N}_{2}$ given their lower solubility. According to Berner and others (1977), the fraction of gases that dissolve after contact of the bubbles with meltwater will depend on the saturation degree of the water, on the bubble gas pressure and on the duration of contact.

Eventually, if the thermodynamic conditions for liquid vein persistence cannot be maintained (as a result, for example, of local changes in the stress, strain or temperature fields), the veins may partly freeze. Such freezing will most likely occur in an open system, since the liquid veins are to some extent interconnected within the ice matrix (Nye, 1989). Differential gas reincorporation should consequently take place at the freezing front, mainly driven by the difference in diffusion coefficient of individual gas species present in the melt phase (Weiss and others, 1972; Souchez and others, 1993). In this process, $\mathrm{O}_{2}$, which is more diffusive in liquid water than $\mathrm{N}_{2}$ and $\mathrm{CO}_{2}$ (Stauffer and others, 1985), will escape more rapidly from the solidification front and will therefore be depleted in the new increments of ice, whereas $\mathrm{CO}_{2}$ will be enriched due to the combined effect of low diffusivity and high solubility. Under repeated such intergranular phase changes, ice showing an increased activity of the interstitial fluid phase will finally undergo gas composition alteration through preferential incorporation of both the more soluble and the less diffusive components. Though we are aware that numerical modelling is required to test our model (a proper knowledge of the interstitial fluid behaviour as well as of the gas properties in these fluids is required in this task), we surmise that this model may qualitatively explain not only the $\mathrm{CO}_{2}$ enrichment observed at the structural interfaces from the laminated subfacies but also the anticorrelation between the $\mathrm{O}_{2}$ and $\mathrm{CO}_{2}$ profiles. The minute loss of total gas volume from the debris-rich ice sequence despite the strong variability of the gas composition might similarly be accounted for.

\section{SUMMARY AND CONCLUSION}

In this paper, we analyze the ice crystal textures as well as the gas content of cold and debris-laden basal ice $\left(-17^{\circ} \mathrm{C}\right)$ excavated from a subglacial tunnel at the margin of Taylor Glacier. Two contrasting ice facies are recognized: an englacial and a stratified facies, the latter being divided 
into two subfacies (laminated and massive). The basal part of the glacier is found to have undergone intense shearing processes, as indicated by the morphology of structural features observed throughout. In other respects, the gas and textural results lead to the assertion that enhanced interactions between gas bubbles and interstitial thin water films occurred at the structural interfaces of the ice sequence as a consequence of localized shearing. The central argument we make in this regard is that the $\mathrm{CO}_{2}, \mathrm{O}_{2}$ and $\mathrm{N}_{2}$ concentrations of the laminated subfacies reflect the occurrence of melting-refreezing events in an open system, whereas its total gas content is very close to that of meteoric ice. Moreover, the conspicuous association of gas composition variability with localized zones of dynamic recrystallization in the laminated subfacies strongly supports the fact that either strain localization or slightly increased temperature (or a combination of the two) played a role in the observed gas composition variability. We therefore conclude that the gas composition of debris-laden ice at the base of polar glaciers and ice sheets may derive not only from the initial entrainment processes, but also from synand post-genetic deformation. We believe that this should be taken into account in the perspective of climate reconstruction from the deepest parts of glaciers and ice sheets. Experimental and modelling analysis of the differential gas dissolution mechanisms emphasized in this study (e.g. in Fig. 6) should contribute to advances in this field.

\section{ACKNOWLEDGEMENTS}

We are grateful to K. Cuffey and an anonymous reviewer for their constructive comments. B. Hubbard is acknowledged as scientific editor. We thank the Marsden Fund and the University of Otago for providing financial support for this study, as well as Antarctica New Zealand for the logistical support. This paper is a contribution to the Belgian Scientific Programme on Antarctica (Science Policy Office). D. Samyn acknowledges support of a FRIA grant (National Science Foundation, Belgium).

\section{REFERENCES}

Alley, R.B., J.H. Perepezko and C.R. Bentley. 1986. Grain growth in polar ice: I. Theory. J. Glaciol., 32(112), 415-424.

Anderton, P.W. 1974. Ice fabrics and petrography, Meserve Glacier, Antarctica. J. Glaciol., 13(68), 285-306.

Barnola, J.M., D. Raynaud, A. Neftel and H. Oeschger. 1983. Comparison of $\mathrm{CO}_{2}$ measurements by two laboratories on air from bubbles in polar ice. Nature, 303(5916), 410-413.

Berner, W., P. Bucher, H. Oeschger and B. Stauffer. 1977. Analysis and interpretation of gas content and composition in natural ice. In Isotopes and Impurities in Snow and Ice. Wallingford, Oxon., International Association of Hydrological Sciences, 272-284. (IAHS Publication 118.)

Blunier, T. and others. 1993. Atmospheric methane record from a Greenland ice core over the last 1000 years. Geophys. Res. Lett., 20(20), 2219-2222.

Boulton, G.S. 1970. On the origin and transport of englacial debris in Svalbard glaciers. J. Glaciol., 9(56), 213-229.

Boulton, G.S. 1996. Theory of glacial erosion, transport and deposition as a consequence of subglacial sediment deformation. J. Glaciol., 42(140), 43-62.

Calkin, P.E. 1974. Subglacial geomorphology surrounding the icefree valleys of southern Victoria Land, Antarctica. J. Glaciol., 13(69), 415-429.
Castelnau, O., T. Thorsteinsson, J. Kipfstuhl, P. Duval and G.R. Canova. 1996. Modelling fabric development along the GRIP ice core, central Greenland. Ann. Glaciol., 23, 194-201.

Chinn, T.J.H. 1991. Polar glacier margin and debris features. Mem. Soc. Geol. Ital., 46, 25-44.

Clark, P.U. 1993. Unstable behaviour of the Laurentide Ice Sheet over deforming sediment and its implications for climate change. Quat. Res., 41(1), 19-25.

Clark, P.U. 1995. Fast glacier flow over soft beds. Science, 267(5194), 43-44.

Corte, A.E. 1962. Vertical migration of particles in front of a moving freezing plane. J. Geophys. Res., 67(3), 1085-1090.

Cuffey, K.M., H. Conway, B. Hallet, A.M. Gades and C.F. Raymond. 1999. Interfacial water in polar glaciers and glacier sliding at $-17^{\circ} \mathrm{C}$. Geophys. Res. Lett., 26(6), 751-754.

Cuffey, K.M. and others. 2000. Entrainment at cold glacier beds. Geology (Boulder), 28(4), 351-354.

Daines, M.J. and D.L. Kohlstedt. 1997. Influence of deformation on melt topology in peridotites. J. Geophys. Res., 102(B5), 10,25710,271 .

Dash, J.G., H.Y. Fu and J.S. Wettlaufer. 1995. The premelting of ice and its environmental consequences. Rep. Prog. Phys., 58(1), 115-166.

Denton, G.H., D.E. Sugden, D.R. Marchant, B.L. Hall and T.I. Wilch. 1993. East Antarctic Ice Sheet sensitivity to Pliocene climatic change from a Dry Valleys perspective. Geog. Ann., 75A(4), 155-204.

Echelmeyer, K. and Z. Wang. 1987. Direct observation of basal sliding and deformation of basal drift at sub-freezing temperatures. J. Glaciol., 33(113), 83-98.

Etheridge, D.M., L.P. Steele, R.L. Langenfelds, R.J. Francey, J.M. Barnola and V.I. Morgan. 1996. Natural and anthropogenic changes in atmospheric $\mathrm{CO}_{2}$ over the last 1000 years from air in Antarctic ice and firn. J. Geophys. Res., 101(D2), 4115-4128.

Fitzsimons, S.J., K.J. McManus and R.D. Lorrain. 1999. Structure and strength of basal ice and substrate of a dry-based glacier: evidence for substrate deformation at sub-freezing temperatures. Ann. Glaciol., 28, 236-240.

Fitzsimons, S.J., K.J. McManus, P. Sirota and R.D. Lorrain. 2001. Direct shear tests of materials from a cold glacier: implications for landform development. Quat. Int., 86(1), 129-137.

Fukazawa, H., K. Sugiyama, S. Mae, H. Narita and T. Hondoh. 1998. Acid ions at triple junction of Antarctic ice observed by Raman scattering. Geophys. Res. Lett., 25(15), 2845-2848.

Gilpin, R.R. 1979. A model of the 'liquid-like' layer between ice and a substrate with applications to wire regelation and particle migration. J. Colloid. Interface Sci., 68(2), 235-251.

Glen, J.W., D.R. Homer and J.G. Paren. 1977. Water at grain boundaries: its role in the purification of temperate glacier ice. In Isotopes and Impurities in Snow and Ice. Wallingford, Oxon., International Association of Hydrological Sciences, 263-271. (IAHS Publication 118.)

Gow, A.J. and T. Williamson. 1976. Rheological implications of the internal structure and crystal fabrics of the West Antarctic ice sheet as revealed by deep core drilling at Byrd Station. CRREL Rep. 76-35.

Gross, G.W., C. McKee and C.H. Wu. 1975. Concentration dependent solute redistribution at the ice/water phase boundary. 1. Analysis. J. Chem. Phys., 62(8), 3080-3084.

Guillope, M. and J.P. Poirier. 1979. Dynamic recrystallization during creep of single-crystalline halite: an experimental study. J. Geophys. Res., 84(B10), 5557-5567.

Hemmingsen, E. 1959. Permeation of gases through ice. Tellus, 11(3), 355-359.

Hirth, G. and D.L. Kohlstedt. 1995. Experimental constraints on the dynamics of the partially molten upper mantle. 2. Deformation in the dislocation creep regime. J. Geophys. Res., 100(B8), $15,441-15,449$.

Holdsworth, G. 1974. Meserve Glacier, Wright Valley, Antarctica: Part I. Basal processes. Ohio State Univ. Inst. Polar Stud. Rep. 37. 
Hooke, R.LeB. and P.J. Hudleston. 1978. Origin of foliation in glaciers. J. Glaciol., 20(83), 285-299.

Hubbard, B. and M. Sharp. 1989. Basal ice formation and deformation: a review. Progress in Physical Geography, 13(4), 529-558.

Jacka, T.H. and J. Li. 1994. The steady-state crystal size of deforming ice. Ann. Glaciol., 20, 13-18.

Kamb, W.B. 1959. Ice petrofabric observations from Blue Glacier, Washington, in relation to theory and experiment. J. Geophys. Res., 64(11), 1891-1909.

Kamb, B. 1972. Experimental recrystallization of ice under stress. In Heard, H.C., I.Y. Borg, N.L. Carter and C.B. Raleigh, eds. Flow and fracture of rocks. Washington, DC, American Geophysical Union, 211-241. (Geophysical Monograph 16.)

Kizaki, K. 1969. Ice-fabric study of the Mawson region, East Antarctica. J. Glaciol., 8(53), 253-276.

Kleman, J. 1994. Preservation of landforms under ice sheets and ice caps. Geomorphology, 9(1), 19-32.

Knight, P.G. 1994. Two-facies interpretation of the basal layer of the Greenland ice sheet contributes to a unified model of basal ice formation. Geology (Boulder), 22(11), 971-974.

Langway, C.C., Jr. 1958. Ice fabrics and the universal stage. SIPRE Tech. Rep. 62.

Lawson, D.E. 1979. Sedimentological analysis of the western terminus region of the Matanuska Glacier, Alaska. CRREL Rep. 79-9.

Lawson, W. 1996. The relative strengths of debris-laden basal ice and clean glacier ice: some evidence from Taylor Glacier, Antarctica. Ann. Glaciol., 23, 270-276.

Lliboutry, L. 1971. Permeability, brine content and temperature of temperate ice. J. Glaciol., 10(58), 15-29.

Mader, H.M. 1992a. Observations of the water-vein system in polycrystalline ice. J. Glaciol., 38(130), 333-347.

Mader, H.M. 1992b. The thermal behaviour of the water-vein system in polycrystalline ice. J. Glaciol., 38(130), 359-374.

Martinerie, P., D. Raynaud, D.M. Etheridge, J.M. Barnola and D. Mazaudier. 1992. Physical and climatic parameters which influence the air content of polar ice. Earth Planet. Sci. Lett., 112(1-4), 1-13.

Mulvaney, R., E.W. Wolff and K. Oates. 1988. Sulphuric acid at grain boundaries in Antarctic ice. Nature, 331(6153), 247-249.

Neftel, A., H. Oeschger, J. Schwander and B. Stauffer. 1983. Carbon dioxide concentration in bubbles of natural cold ice. J. Phys. Chem., 87(21), 4116-4120.

Nye, J.F. 1989. The geometry of water veins and nodes in polycrystalline ice. J. Glaciol., 35(119), 17-22.

Passchier, C.W. and C. Simpson. 1986. Porphyroclast systems as kinematic indicators. J. Struct. Geol., 8(8), 831-843.

Paterson, W.S.B. 1994. The physics of glaciers. Third edition. Oxford, etc., Elsevier.

Raymond, C.F. and W.D. Harrison. 1975. Some observations on the behavior of the liquid and gas phases in temperate glacier ice. J. Glaciol., 14(71), 213-233.

Raynaud, D., D. Delmas, J.M. Ascencio and M. Legrand. 1982. Gas extraction from polar ice cores: a critical issue for studying the evolution of atmospheric $\mathrm{CO}_{2}$ and ice-sheet surface elevation. Ann. Glaciol., 3, 265-268.
Raynaud, D., J. Chappellaz, J.M. Barnola, Y. Korotkevich and C. Lorius. 1988. Climatic and $\mathrm{CH}_{4}$ cycle implications of glacialinterglacial $\mathrm{CH}_{4}$ change in the Vostok ice core. Nature, 333(6174), 655-657.

Rempel, A.W., E.D. Waddington, J.S. Wettlaufer and M.G. Worster. 2001. Possible displacement of the climate signal in ancient ice by premelting and anomalous diffusion. Nature, 411(6837), 568-571.

Rigsby, G.P. 1960. Crystal orientation in glacier and experimentally deformed ice. J. Glaciol., 3(27), 589-606.

Robinson, P.H. 1984. Ice dynamics and thermal regime of Taylor Glacier, South Victoria Land, Anatarctica. J. Glaciol., 30(105), 153-160.

Samyn, D., A. Svensson, S. Fitzsimons and R. Lorrain. 2005. Dynamic recrystallization associated with gas composition changes in basal ice from an Antarctic glacier. Geophys. Res. Abstr. 7, 09289. (1607-7962/gra/EGU05-A-09289.)

Sleewaegen, S., D. Samyn, S.J. Fitzsimons and R.D. Lorrain. 2003. Equifinality of basal ice facies from an Antarctic cold-based glacier. Ann. Glaciol., 37, 257-262.

Souchez, R. 1997. The buildup of the ice sheet in central Greenland. J. Geophys. Res., 102(C12), 26,317-26,323.

Souchez, R., M. Lemmens, J.L. Tison, R. Lorrain and L. Janssens. 1993. Reconstruction of basal boundary conditions at the Greenland ice sheet margin from gas composition in the ice. Earth Planet. Sci. Lett., 118(1-4), 327-333.

Souchez, R., D. Samyn, R. Lorrain, F. Pattyn and S. Fitzsimons. 2004. An isotopic model for basal freeze-on associated with subglacial upward flow of pore water. Geophys. Res. Lett., 31(2), L02401. (10.1029/2003GL018861.)

Stauffer, B., A. Neftel, H. Oeschger and J. Schwander. 1985. $\mathrm{CO}_{2}$ concentrations in air extracted from Greenland ice samples. In Langway, C.C., Jr, H. Oeschger and W. Dansgaard, eds. Greenland ice core: geophysics, geochemistry, and the environment. Washington, DC, American Geophysical Union, 1-8. (Geophysical Monograph 33.)

Sugden, D.E. and B.S. John. 1976. Glaciers and landscape; a geomorphological approach. London, Edward Arnold.

Thorsteinsson, T., J. Kipfstuhl, H. Eicken, S.J. Johnsen and K. Fuhrer. 1995. Crystal size variations in Eemian-age ice from the GRIP ice core, central Greenland. Earth Planet. Sci. Lett., 131(3-4), 381-394.

Tison, J.L. 1994. Diamond wire-saw cutting technique for investigating textures and fabrics of debris-laden ice and brittle ice. J. Glaciol., 40(135), 410-414.

Tison, J.L., J.R. Petit, J.M. Barnola and W.C. Mahaney. 1993. Debris entrainment at the ice-bedrock interface in sub-freezing temperature conditions (Terre Adélie, Antarctica). J. Glaciol., 39(132), 303-315.

Weiss, R.F., P. Bucher, H. Oeschger and H. Craig. 1972. Compositional variations of gases in temperate glaciers. Earth Planet. Sci. Lett., 16(2), 178-184.

Wettlaufer, J.S. 1999. Impurity effects in the premelting of ice. Phys. Rev. Lett., 82(12), 2516-2519.

Wilson, C.J.L., Y. Zhang and K. Stüwe. 1996. Effects of localized deformation on melting processes in ice. Cold Reg. Sci. Technol., 24(2), 177-189. 